\title{
日本の製紙産業の特質と課題
}

王子製紙株式会社 社長 河 毛 二 郎

\section{Characteristics and Tasks of Japan's Pulp and Paper Industry}

\author{
Jiro Kawake \\ Oji Paper Company, Ltd.
}

5 月27日から 3 日間, 米国シフトル市のワシントン 大学で, 同大学主催（協替：日本製紙連合会, 米国製 紙協会, カナタ紙パルブ協会）による「紙パルブ産業 に於ける課題と見通し国際シンポジウム」が開催され た。

世界主要各国から招かれた 30 名の講師により，各 地域の紙パ産業の現状と見通しについて報告があり， 日本加らは王子製紙河毛社長が出席され，「日 本の製紙産業の特質と課題」と題して(1)資源小国の日 本がどらやって世界第二位の製紙国になることがでさ たか（2国祭化が進む中で日本の紙パ産業はどら対応 してゆくか（3)これからは製品の多様化，情報化時代 への適応が大きな課題である……などについて英語で 講演された。

(編集部)

\section{日本の製䌅産業の特犋}

日本は現在年間約 2,000 万 $\mathrm{t}$ の紙を生産し，消費す る国であります。何れもU.S.A. に次いで世界第 2 位 の量であり，世界の総量の $11 \%$ に相当致します。こ のように世界でも有数の製紙国である日本の製紙産業 はどの上うな特質をもっているのでしょらか。

先す製紙原料構成に御注目願いたいと思います。

(1) 消費原料の約 $50 \%$ が古紙である

(2) パルブ用原木の自給率は約 $60 \%$ である

世界の主要製紙国が何れも殆ど木質原料依存し， しかもパルブ用原木を自給していることを考党ると非 常にニニークな形であります。

しかしながらこのような特色が定着したのは実は 約 10 年前からであって，それまでは日本も古紙を含 めてでありますがほほ原料を自給できる国であった訳 です。

このような变化を表 1 に示された紙の生産量の増加

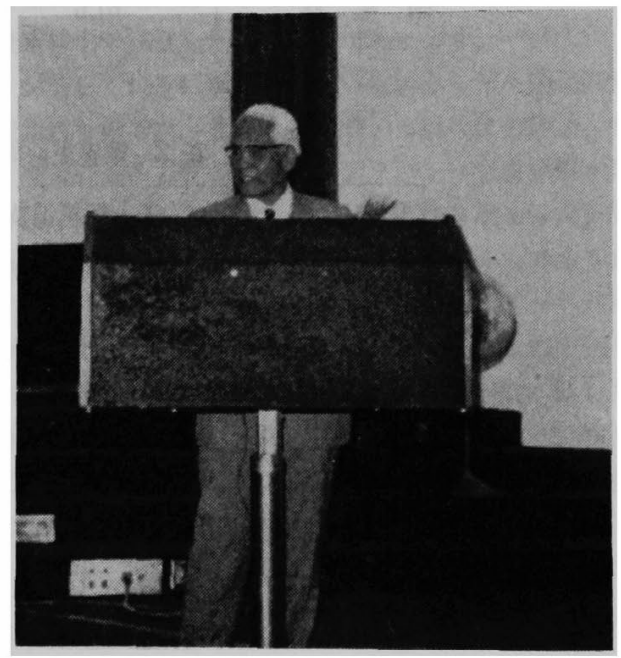

と対応させると，700万 $\mathrm{t}$ からせいせい 1,000 万 $\mathrm{t}$ 位 が原料自給の限界であったかと思われます。

日本が製紙原料の自給という一つの大きな壁を越え て，国内生産を払大できたのには幾つかの理由がある と思われます。

第一に古紙の徽底的な回収之利用であります。

このよらに日本が世界の主要国の中で群を抜いて高 い古紙利用ができたのは，狭い国土と過密な人口が逆 にその面では好都合な条件となっているからで，紙全 体の回収率は $50 \%$ に達し，特に新聞古紙は $93 \%$, 段 ボール古紙は76\%といら高い回収率を示して扰りま す。またその利用は板紙分野から急速に紙分野に拡大 し, それを可能にしたのは脱量, 異物除去, スライム コントロール剤など独特の技術開発の裏付けがあった からであります。

しかしながら,最も画期的な出来事は, 1965年U.S.A. 西海岸から尃用船により廃材チップが輸入されたこと 


河 毛 二 郎

表 1 紙の生産と原料構成推移

\begin{tabular}{|c|c|c|c|c|}
\hline & 1985 年 & 1975 年 & 1965 年 & 1955 年 \\
\hline 紙の生産 & 20,469 千t & 13,601 千t & 7,299 千t & $2,204 千 \mathrm{t}$ \\
\hline 消費原料中の割合 & & & & \\
\hline 古 紙 & $49.3 \%$ & $36.6 \%$ & $34.6 \%$ & $20.1 \%$ \\
\hline パ ル プ & 50.5 & 62.9 & 60.5 & 66.8 \\
\hline その他織維 & 0.2 & 0.5 & 4.9 & 13.1 \\
\hline 原料パルプ割合 & & & & \\
\hline 榆入パルプ & $8.7 \%$ & $5.3 \%$ & $3.2 \%$ & $0.5 \%$ \\
\hline 国産パルブ & 41.8 & 57.6 & 57.3 & 66.3 \\
\hline 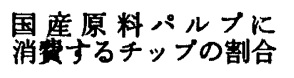 & & & & \\
\hline 渝入チップ & $38.4 \%$ & $40.0 \%$ & $3.1 \%$ & $0 \%$ \\
\hline 国 産 材 & 61.6 & 60.0 & 96.9 & 100 \\
\hline
\end{tabular}

出典 : 通産省「紙パルプ梳計年報」

表 2 世界主要国の古紙回収比率（1985 年）

\begin{tabular}{|c|c|c|c|c|c|c|}
\hline 国 & 紙・板紙消費量 & 回 & 収 & 回 & 収 & 率 \\
\hline 日 & $\begin{array}{l}\text { 千Mt } \\
20,303\end{array}$ & & $\begin{array}{c}\text { 千Mt } \\
10,152\end{array}$ & & 50.0 & \\
\hline 米 & 67,966 & & 17,868 & & 26.3 & \\
\hline カ ナ & 5,085 & & N. A. & & - & \\
\hline 英 ～～ & 7,796 & & 2,171 & & 27.8 & \\
\hline 西 & 10,625 & & 4,371 & & 41.1 & \\
\hline ᄀ ラ ン & 6,556 & & 1,936 & & 29.5 & \\
\hline フィンラン & 1,348 & & 342 & & 25.4 & \\
\hline スウェーデ & 1,962 & & 763 & & 38.9 & \\
\hline ハルウェ・ & 563 & & 131 & & 23.3 & \\
\hline
\end{tabular}

出典：P P I 誌

表 3 紙の主要消䨳国・生産国

\begin{tabular}{|c|c|c|c|c|c|}
\hline 国 & 消 費 量 & (A) & 生 産 量 & (B) & $\mathrm{B} / \mathrm{A}$ \\
\hline 日 & $\underset{20,303}{\mp M t}$ & ランク & $\begin{array}{c}\underset{7 M t}{ } \\
20,469\end{array}$ & ランク & $101 \%$ \\
\hline 米 & 67,966 & 1 & 61,121 & 1 & 90 \\
\hline 西 & 10,625 & 3 & 9,178 & 5 & 86 \\
\hline 中 & 9,693 & 4 & 9,112 & 6 & 94 \\
\hline y & 9,250 (推) & 5 & 9,950 (推) & 4 & 108 \\
\hline 英国 & 7,796 & 6 & 3,766 & 12 & 48 \\
\hline フランス & 6,556 & 7 & 5,343 & 9 & 81 \\
\hline イタ リ & 5,211 & 8 & 4,587 & 10 & 88 \\
\hline カ ナ タ & 5,085 & 9 & 14,448 & 3 & 284 \\
\hline フ ラ シ ル & 3,632 & 10 & 4,054 & 11 & 112 \\
\hline スウェーデン & 1,962 & 17 & 7,003 & 8 & 357 \\
\hline フィンランド & 1,348 & 21 & 7,444 & 7 & 352 \\
\hline
\end{tabular}

(推) $=$ 推定

出典 : P P I 誌 
であります。それまで利用方法のないまま繶却されて いた廃材を海を利用する大量榆送により経済性のある 資源に転したアイデアは，日本の製紙業にとっては音 速の壁を越えたジェット機の開発にる相当すると言っ ても過言ではありませんし，その時からアメリカのウ エストコーストKとって，日本は東部や南部より近い 国となった訳です。この傾向は今では豪州, ニュージ ーランド，東南アジフなど，いわゆるパシフィック・ リムと呼ばれる広い地域にまで広がりつつあり，今に して思えばまさに日本の紙パルブ産業にとって国際化 時代の始まりでありました。

次に大きな特色は，日本は紙の国内消費をはほ 100 \%国内の生産て睄っていることであります。世界の他 の主要国は殆ど紙については愉出国であるか榆入国で あるか，何れかであります。

製纸業のようにその眅路を殆ど国内市場に依存して いるといらことは, 榆出主導型の日本の産業の中でも 極めて特異な事例であります。しかる国内の紙の需要 は GNP の成長には㤬相関して增加してきており，今 後とる 2 3\% の伸びが期待できると思われます。

足下に世界第 2 位の成長性のあるマーケットをもっ ていることは, 日本の製紙産業存立の大変重要な条件 になっているのであります。

また，前述のよらに原料自給の壁を越えて紙の生産 が払大されてきた理由の中に，世界のどの国よりむ厳 しい需要家の品質に対する要求と, デリバリーについ
てのサービスといらマーケットの特色をあげなければ なりません。自らが生産することなしに，需要家一人 一人の求めに応ずるような品質は達成でさないし，ま たその日その日, 必要なだけ製品を届けるようなデリ パリーサービスはできないからであります。

第三に，何といってる資源小国である日本のハンデ イキャップを克服するため，色々な努力がなされてい るといらことであります。

原料調達については既に触れましたので, エネルギ 一を例にとって和話したいと思います。1979年の石 油価格が一挙に 4 倍になる高騰は, 日本の製紙産業に とって文字通りオイルショックでありました。その後， オイルそのものの使用の減少と, 石炭など更に安い代 替然料の利用にあらゆる努力が傾注されたのは当然で, 表 4 はその経過を示したものであります。

おそららく世界に類例をみない省エネルギー効果が実 現されたのであります。生産設䜤の近代化の推進もま た企業の競争力を高めてハンディキャッブを克服する 有効な手段でありました。約 10 年前に始まった新聞 用紙の軽量化の進展は皆さん御承知のところでありま すが，用紙メーカーとしての諸対策の中で，ペーパー マシンのッインワイヤー化はその代表的なるのであり ます。現在，日本の新聞用紙用抄紙機台数は 40 台あ り, 内ッインワイヤー方式のものは 33 台 $(82.5 \%)$ であります。現在この方式による生産実積もまた総量 の $94 \%$ に達しています。

表 4 エネルギー消費推移

\begin{tabular}{|c|c|c|c|c|c|c|c|c|c|c|c|}
\hline \multirow{2}{*}{ 年 } & \multicolumn{3}{|c|}{ 椥 } & \multicolumn{3}{|c|}{ 料 } & \multicolumn{2}{|r|}{ 購 } & \multicolumn{2}{|l|}{ 入 } & 力 \\
\hline & 重 & 油 & 石 & 宸 & 原 & 単 位 ${ }^{(* 1)}$ & 電 & 力 & 量 & 原 & 単 \\
\hline 1973 & & $\begin{array}{c}千 \mathrm{f} l \\
7,280\end{array}$ & & $\underset{136}{\mp \mathrm{t}}$ & & $\begin{array}{l}\mathbf{k} l / \text { 紙 } t \\
0.461\end{array}$ & & $\begin{array}{r}\text { 面 } \\
8,86\end{array}$ & $\mathrm{kWh}$ & & $\underset{555}{\mathrm{kWh} / \text { 紙 }}$ \\
\hline 74 & & 7,241 & & 170 & & 0.469 & & 8,782 & & & 561 \\
\hline 75 & & 6,953 & & 89 & & 0.515 & & 8,442 & & & 621 \\
\hline 76 & & 7,315 & & 67 & & 0.478 & & 9,533 & & & 619 \\
\hline 77 & & 7,264 & & 59 & & 0.465 & & 9,776 & & & 623 \\
\hline 78 & & 7,287 & & 43 & & 0.443 & & 10,463 & & & 634 \\
\hline 79 & & 7,102 & & 85 & & 0.400 & & 11,298 & & & 633 \\
\hline 80 & & 6,367 & & 238 & & 0.360 & & 12,025 & & & 665 \\
\hline 81 & & 5,174 & & 453 & & 0.321 & & 11,870 & & & 699 \\
\hline 82 & & 4,779 & & 602 & & 0.295 & & 12,044 & & & 690 \\
\hline 83 & & 4,536 & & 958 & & 0.278 & & 12,209 & & & 662 \\
\hline 84 & & 4,553 & & 1,001 & & 0.267 & & 12,283 & & & 635 \\
\hline 85 & & 4,325 & & 1,076 & & 0.244 & & 12,560 & & & 616 \\
\hline
\end{tabular}

*1：石炭・重油換算量を含む 出典：通産省「紙パルブ統計年報」 


\section{日本の製紙産業の課題}

以上，日本の製紙産業の特色を挙げながら，現状を 扣話致しましたが，それでは今後の課題は何かと申し ますと

(1) 国際化への対応

（2）製品の多様化と情報化時代への対応

の二つに要約されると思います。

\section{国際化への対応}

外国からのチップの渝入が国際化への第一歩であっ たことは，既に申し上げましたが，約 15 年前から徐 々にではありますが, 日本企業が海外に進出して, 主 として日本で使用または肘壳することを目的としてパ ルプあるいは紙を製造する事例が現れております。

表 5-1はハハルプ事業について，これまでの実績を一 覧にしたものでありますが，6事例中 1 例を除いて 1960 年代の末から 1970 年の初めまでの時期に設立さ れており，ちょらどオイルショック直前の日本経済の 高度成長期の最終段階に当って招り, その当時, 予想 された日本の紙の高い成長見通しを前提としてチップ に次ぐ原料ソースとしてパルプが着目されたものであ ります。カナダ $\mathrm{BC}$ 州, ニュージーランドでの TMP の生産はその代表的なものであり, またスプルース系 のすぐれた長緎維パルプとして NBKP, ブラジルの ユ一カリの植林の成長性に着目した LBKP など，そ れぞれ特色のあるものであります。何れも現地側パー トナーとの合升事業となっております。

しかしながら，この形のパルブ生産は, 日本経済が 低成長期に入ると共にその後はかばかしい進展をみせ て扣りません。

1970 年代の後半, 日本の製紙会社がそれぞれアメリ カとカナダで現地の製紙メーカーと合弁で新聞用紙ま たは新聞グレードの紙を生産し，日本のマーケットに 開発輸入したことは国際化の更に新しい一つのトレン ドでありました。しかしながら1980年に始まった紙 パルブ産業の世界的な不振と, 日本における設䜤能力 の過剩が相まって, その後大きな発展をみず, 現在に 至って扣りますが，。し外国の紙製品が日本のマーケ ットに参入するとすれば，最す現実的，かつ適切な方 法であることを示した武みであったと考兄られます。 さて，ここ数年来の貿易摩擦之昨今の急做な円高と いう，日本経済にその基本構造の転換を求められてい る時代の波は，日本の製紙業にとっても更に国際化を 進展させる大きなモメントであると考えて良いと思い ます。

更に，現状において日本の紙パルプ生産設備能力は，
な和需要を $15 \%$ 程度上迴っていると推定されますが、 年平均 $2.4 \%$ の需要の伸び（日本製紙連合会）が見通 されて扣りますので, 今後 5 年以内に需給がバランス すると考えて差し支えありません。新しい供給ソース を何に求めるか，今断言することはでさせんが，従 来の原料輸入 ・国内生産の增強といらパターンだけで なく, 品種によっては開発輸入といら国際化の方向も 充分検討されるべきすのであります。

昨年から本年にかけて，日本の製紙メーカーが米国 に㨟いて板紙会社を買収, 或は株式取得した事例はそ の魁と解して良いのかもしれません。

しかしながら，日本の市場に開発輸入といら形であ っても参入するのには色々難しい問題があり, 当事者 がその解決に真剣に取り組むことによってのみ，現寒 化するものであることを指摘し，特に海外の皆様の御 理解を頂きたいと思います。

(1) 相当量の製品をコンスタントに長期に亘って 供給できる体制ができるか(含労使関係の安定)

(2) 日本市場特有の品質要求, デリベリー・サー ビスを如何にして確保するかの方法, 特に合升 事業に批ける日本側の立場が品質について十分 確立できるほどしっかりしたものであること

(3) 日本側と現地側のパートナーとしての権利, 義務の公平

\section{慗品の多槏化と情報化時代への対応}

近年, 日本に拈ける紙の需要の多様化は著しいもの があります。しかも先ず在来品の分野でそれは起こり つつあります。例えば，新聞用紙は最も一般的な大量 生産品種と考えられておりますが，印刷用紙の多様化 とカラー印刷の普及，色刷新聞の登場など，今や新聞 社ごとや印刷所ごとに特注品を造っていると考觉てよ い時代になりました。

上質紙，塗工紙の分野です軽量紙の進展，ベースペ ーパーのグレードダウン，塗工技術の多様化（サイズ プレス品, ゲートロール品, 微叙工紙など）更には, スーパーカレンダーの活用などによって多くの中間品 種を生み出し，まさに塗工紙の戦国時代と言われて拉 ります。

表 6 でおかかかりの通り，10 年前, 焦工紙の大部分 を占めていたコート紙（A2，アート紙（A1）は現 在，上質ベースまたは中質べースの軽量等工紙にその 席を㵝り，新しい分野はまたその成長率も王倒的に高 い。特に新しく登場した微塗工紙（ゲートロール品が 中心）はコート紙の分野の外にいながらコート紙並み の機能をもつ商品として需要家の要求も強く, 本品を 商品としてどら位置つけるかが 今問題となっです 


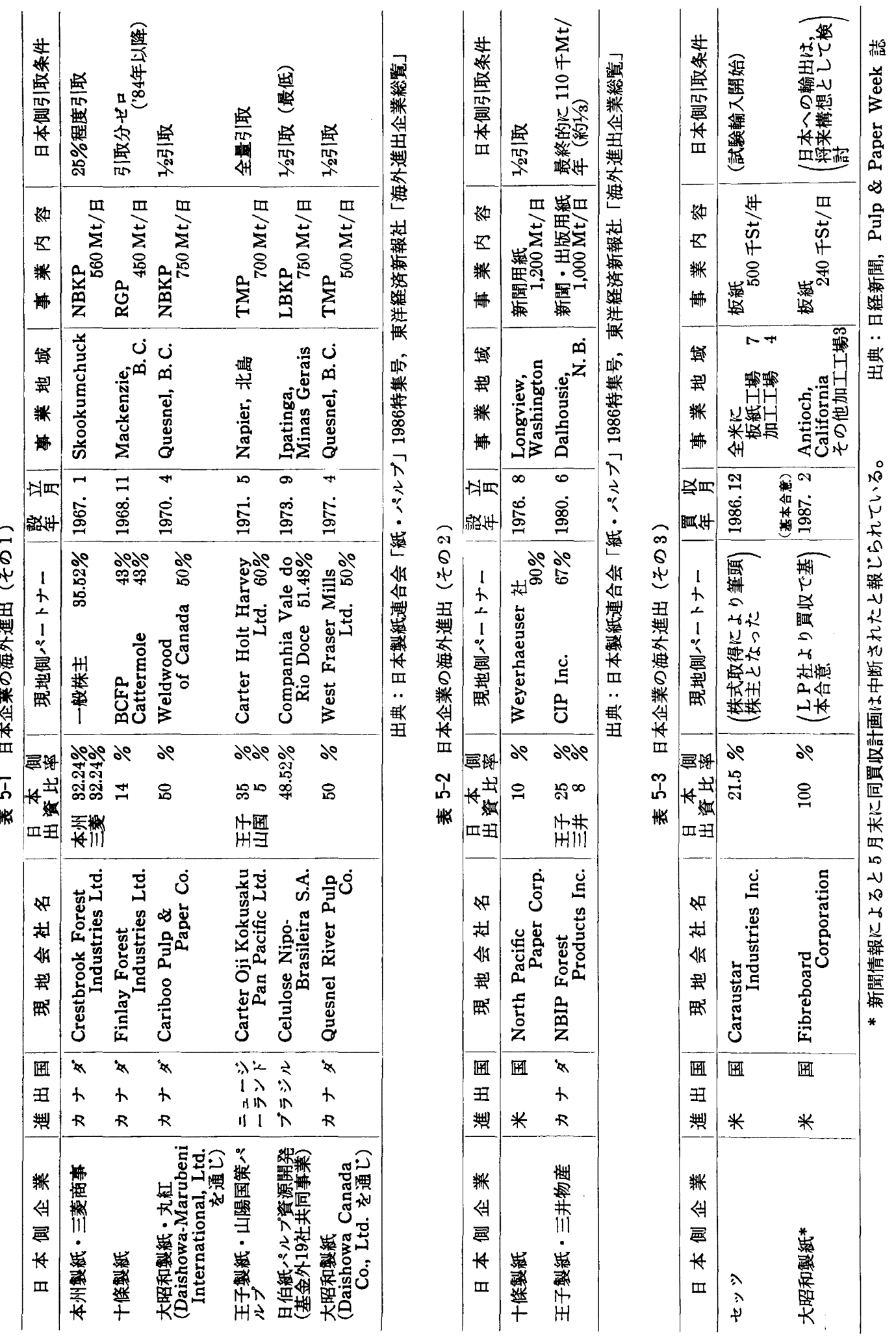



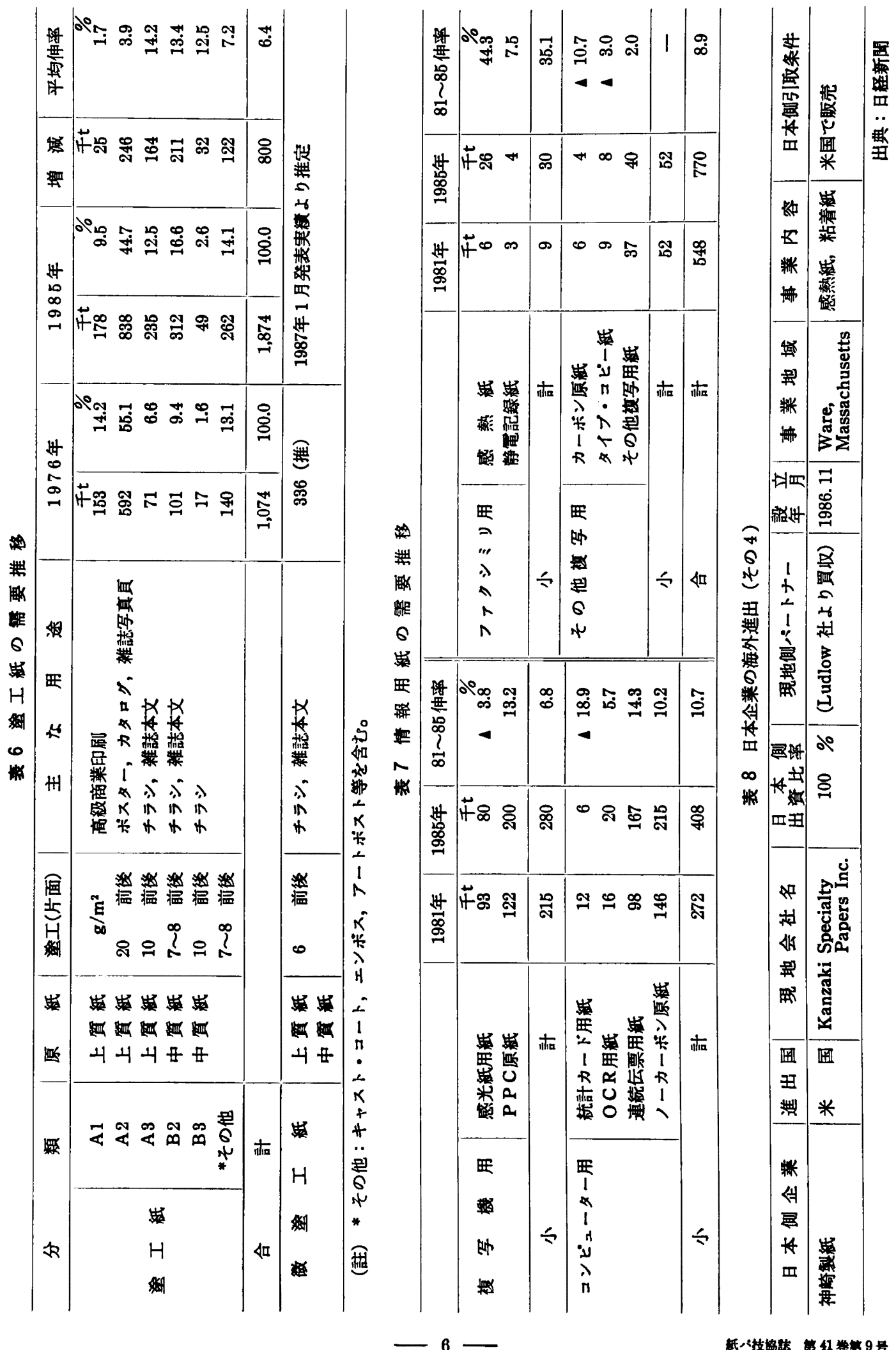
ます。世界的にみても LWC は近年最も急成長した品 種であり，やや供給過鄱の状態すら見受けられますが， 何れにせよ紆余曲折を経ながらす製品の多様化は今後 とす進むすのと考光ております。

次に，需要の多様化はまた新製品の開発につながる るのでありますが, 中でも情報化，すなわち, computer and communications の発達にマッチした情報用 紙の開発と供給はその中心であり，まさに時代の要請 であります。

表 7 は 1981 年と 1985 年の日本における情報用紙の 需要の推移をまとめたものでありますが，この間， 8.9\%という高い伸び率を示しており，特にぜロック スなどに使われる PPC 原紙（plain paper copy）, 連続云票用紙，ノーカーボン原紙などのコンピュータ 一用フォーム用紙, 静電記録紙, 感熱記録紙などのフ フクシミリ用紙などを中心に今後も高い伸びを示すも のと思われます。同時に情報用紙はハードの発達その 他により品質・機能など今後ともどしとし新しいもの， 進歩したものが求められる分野であり，開発と商品化 の能力が鍵であります。その方向は

(1カラー化特に PPC 原紙, 更にはウィデオ・ プリンターなど
(2)スピート゚化

ファクシミリのG3よりG4（一分 機から数秒機) への発展に対応す る用紙の開発 (laser printing)

(3)普及化 10万円以下のフォクシミリ，コピ 一機, ワープロ, パソコンなど, 普及型への用紙の対応

等であろらかと思われます。

日本は感熱記録紙，ノーカーポン紙の分野では欧米 に輸出しており，加工度の高い新しい技術に裹付けら れた用紙については，日本とい党ども，海外市場に進 出できることを示しております。また最近の円高の急 速な進展に伴い，従来の榆出市場に現地会社を買収し て現地で生産して供給する新しい動向も現れ，国際化 の今一つの型を作りつつあります。

日本の製紙産業てついて語るべきことは，まだまだ つきせんが与えられた時間の制約もあり，以上のよ らに取りまとめました。今後ますます国際化といらこ とが私共の一つの大きな贸題になっている中で，特に 諸外国の皆様に日本の製紙産業を理解して頂くことに 何が役に立つようにと願ってょります。 